\title{
HEALTH PROMOTION INSTRUCTIONS FOR PREGNANT WOMEN WITH IRON DEFICIENCY ANEMIA IN PORTSAID CITY
}

\section{Bassma Assem Brawy ${ }^{1}$, Dr.Gehad Mohamed Abo-Elmaty ${ }^{2}$, Dr. Inaam Hassan Abdel-Ati ${ }^{3}$, Dr. Nahed Abdel-azeem Adel-Salam ${ }^{4}$ \\ B.Sc. nursing ,Faculty of nursing -port-said university ${ }^{1}$,Prof. of family and community health \\ Nursing, Faculty of Nursing Port Said University², Assistant Prof of Maternity, Obstetric\& Gynecological Nursing, Faculty of Nursing, Port Said University ${ }^{3}$, Family and Community \\ health Nursing, Faculty of Nursing, Port Said University ${ }^{4}$}

\begin{abstract}
Background: Health promotion is the process of enabling people to increase control over, and to improve their health by focusing on individual behavior. Aim: Apply health promotion instructions for pregnant women with iron deficiency anemia in Port said city. Research design: A quasi_expeimental research design was used. Setting: Study was conducted in six Mother and Child health centers in Port Said city. Sample: A purposive of 180 pregnant women divided into 90 study group and 90 control group. Tools: Three tools were used to collect data, interviewing questionnaire, food frequency questionnaire, and assessment recording which include anthropometric assessment laboratory investigations and medical prescribed .Results: Results indicated that no statistical significant difference between the control and study group regarding socio_demographic characteristic and obstetric history meanwhile there are significant improvement in the study group knowledge about iron deficiency anemia and its management . The study subjects according to their mean hemoglobin level before and after the intervention. It is obvious that the mean hemoglobin level did statistically increase among the study group after application of health promotion instructions compared to those in the control group. Conclusion: Application of promotion instructions enabling pregnant women to increase control over their own health, beyond focus on individual behavior towards a wide range of social and environmental interventions which in turn improve their anemia and their life style regarding their diet knowledge and practice . Recommendations: further study for including issue about anemia and its prevention ways within pre-marital counseling.
\end{abstract}

Keywords: Health promotion; Iron deficiency anemia; pregnant women. 


\section{INTRODUCTION}

Anemia is a global public health problem affecting both developing and developed countries with major consequences for human health as well as socio-economic development. It occurs at all stages of the life cycle but is more prevalent in pregnant women and young children; the prevalence rate of iron deficiency anemia among pregnant women worldwide is $55.8 \%$ compared to $58 \%$ in developing countries. Anemia affects about $18 \%$ women during pregnancy in developed countries most of them were already anemic at the time of pregnancy (Addis Alene, \& Mohamed 2014).

Iron deficiency anemia is a common type of anemia - a condition in which blood lacks adequate healthy red blood cells. Red blood cells carry oxygen to the body's tissues. As the name implies, iron deficiency anemia is due to insufficient iron. Without enough iron, your body cannot produce enough of a substance in red blood cells that enables them to carry oxygen (hemoglobin). As a result, iron deficiency anemia may leave you tired and short of breath. Its signs and symptoms may include extreme fatigue, Weakness, Pale skin, Chest pain, fast heartbeat or shortness of breath, Headache, dizziness or lightheadedness, Cold hands and feet, Inflammation or soreness of your tongue, Brittle nails, Unusual cravings for non-nutritive substances, such as ice, dirt or starch, Poor appetite, especially in infants and children with iron deficiency anemia.

Health promotion is "the process of enabling people to increase control over, and to improve, their health Therefore, health promotion is not just the responsibility of the health sector, but goes beyond healthy life-styles to well-being (World Health organizationsOttawa charter 1986and slightly modified in 2005 in WHOsBangkok Charter for Health promotion 2005).

Preventing anemia during pregnancy is as easy as changing, or making additions, to your diet. Medical professionals recommend a pregnant woman eat $30 \mathrm{mg}$ (at least three servings) of iron each day as (Lean, red meats and poultry, Eggs, Dark, leafy green vegetables (such as broccoli, kale, and spinach), Nuts and seeds, Bean, lentils, and tofu). Because it can be a challenge to eat as much iron as is suggested during pregnancy, taking iron supplements is recommended in addition to consuming these foods. Foods that are high in vitamin $\mathrm{C}$ can 
actually help the body absorb more iron, so it is beneficial to make these additions as well. Vitamin C rich foods include Citrus, Fruits, juices, Strawberries, Oranges, Kiwis, Tomatoes, Bell peppers. After delivery, blood volume and plasma levels are expected to return to normal. This may take care of any anemia concerns that develop later in pregnancy. This should not keep pregnant women from seeking care for anemia during pregnancy.( Ainsworth\& Weiss 2015).

Primary health care nurses play a vital role in promoting health during pregnancy. The nurse's role within the aspect of health promotion has shifted from a disease model to a health model. The most important role is figured in teaching the pregnant women the importance of routine iron supplementation and frequency measuring the hemoglobin level. The other crucial role is instructing and informing the mother about the importance of maintaining health during pregnancy especially those related to nutritional aspects, and change their eating habits and practices that contribute to nutritional deficit. -- (Abdelhafez, El-Soadaa 2012)

\section{Significance of study:}

According to the United States Agency for International Development (USAID, 2011) anemia affects more than 500million women in developing countries do where four of every 10 pregnant women and 3 of every 10 non-pregnant women are anemic. Iron deficiency anemia is determined as hemoglobin values less than $11 \mathrm{~g} / \mathrm{dl}$ of blood. According to WHO anemia ranges from mild, moderate to severe and the WHo pegs the hemoglobin level for each of these types of anemia in pregnancy at 10.0 - 10.9g/d1 "mild anemia" $7-9.9 \mathrm{~g} / \mathrm{dl}$ "moderate anemia" and < 7g/dl "severe anemia” (Mirzaie et al., 2010)

Despite the high prevalence and serious consequences of anemia in Egypt and other developing country, a variety of interventions for anemia prevention and control are available, addressing all the major causes, but experience with effective protocol for management has been limited so the present study is undertaken. 


\section{AIM OF THE STUDY}

The present study aims to apply health promotion instructions for pregnant women with iron deficiency anemia in Port Said city.

\section{SUBJECT AND METHOD}

\section{Study design:}

A quasi-experimental research design with pre-post assessment (Control group \& Study group) was used.

\section{Study Setting}

The present study was carried out in in six Mother Child Health Care (MCH) Center in Port Said city. These centers selected randomly from twenties primary health care centers representing the six districts of Port-said according to the capacity of centers and registered cases, namely.

\begin{tabular}{|l|l|}
\hline Name of center & $\begin{array}{l}\text { Number of pregnant } \\
\text { women }\end{array}$ \\
\hline Kuwait Centre(Eldawahy district) & 49 \\
\hline Elmanakh child care (Elmanakh district) & 26 \\
\hline Elarab first (El Arab district) & 22 \\
\hline Osman ebn a fan center (Elzohor district ) & 53 \\
\hline Maternal and child first Arab (Elshark district) & 21 \\
\hline Port-Foad first (port-foad district) & 9 \\
\hline
\end{tabular}

\section{Types of sample}

Purposive sample of pregnant women was used in this study

\section{Tools of data collection}

Three types of tools were used for collection of data 


\section{Tool 1: Interviewing questionnaire}

A structure questionnaire sheet was developed by the researcher to collect the necessary data. It was conducted after the reviewing of literature related to health believe model and iron deficiency anemia. The sheet was in Arabic language and consist of four parts including: Part one; Woman's socio-demographic data and maternal history such as (age, education level, occupati0n.....etc.). Maternal history, which include (gravidity, parity, weeks of gestation, current pregnancy symptoms and antenatal care. Number of abortion....etc.)

Part two: question related to women knowledge regarding iron deficiency anemia e.g. Definition, causes, clinical picture...etc.

Part three: question related to pregnant women's perception (pre-post tool). It consisted of the constructs of HBM. Questions for assess women perception for susceptibility, severity, benefits, barriers, self- efficacy and cues to Action.

Part four: question related to pregnant women's practices (pre-post tool); it composed of two elements; the first one to assess the women's eating practices and the second one to assess the women cocking habits.

\section{Scoring system}

For each knowledge question, a correct response was scored two and the incorrect 1 (Satisfactory knowledge for complete answer and unsatisfactory knowledge for incomplete answer \& don't know). For each area of knowledge, the scores of the items were summed-up and the total divided by the number of the items, giving a mean score for the part. These scores were converted into a percent score. Knowledge was considered Good, very good or poor not satisfaction: if the percent score was less than 60\%, and Satisfactory: if the percent score was $\geq$ $60 \%$. In addition, the question components of the model had 3 point Likert score options, the summed interval scale method was used; which indicated that, every response was given points from 1 - 3 respectively, then, the final score for the respondent was the sum of their ratings for all of the items. These scores were converted into a percent score, and means and standard deviations were computed 
Scoring of the questions or phrases for dietary behaviors were considered as well as ratings: Level 1 unsatisfactory (poor dietary behaviors if score is $<60 \%$ ), participants who had poor dietary behaviors or did not follow the healthy diet, level 2 satisfactory (optimal or good dietary behaviors, if score is $\geq 60 \%$ ), who acted strictly in accordance with the instructions for proper nutrition during pregnancy.

For assessing women dietary habits and reported cooking practices, and medication prescribed. 11 questions including HBM construct. The performance questions were based on self-report and consumption of iron enhancing diet as well as cooking habits and each had three choices ("never", "sometimes" and" always"). Each answer was given zero to two points. Finally, the total score of each segment was converted into percent.

\section{Tool II: Food frequency questionnaire (FFQ)}

This tool was designed by (Theodora Mouratidou,2006) and it was modified by the researcher . This part included frequency response formats to recall each pregnant diet. The food intake frequencies were classified into four categories: rarely, a time per week, 2-5 times per week and more than 5 times per week. The questionnaire included the most important items that are rich or poor in iron or influences the iron absorption. For the purpose of presenting the above mentioned tool in the pre and post test result it was summarized into 6 parameter and scaled as: Never= rarely, Sometimes $=$ once per week, often $=2-5$ time/week and Always $=$ more than 5 time/week

\section{Tool III: Assessment recording}

It consists of three parts; Part one: Anthropometric assessment: The height was measured and pregnant women's were asked to report their pre-pregnancy weight and pre-pregnancy Body Mass Index (BMI) was then calculated as weight in kilograms divided by the square of height in meters .Scoring of body mass index(BMI):According to World Health organization(WHo) BMI is a value derived from the mass (weight) and height of a person .It based on a tissue mass ( muscle ,fat ,bone, height) and divided by the square of the body height, and is universally expressed in units of $\mathrm{Kg} / \mathrm{m} 2$, resulting from mass in kilograms and height in meters. It's categories: Underweight(less than 18,5k g/m2), Normal weight $(18,5 \mathrm{~kg} / \mathrm{m} 2$ t0 25 $\mathrm{g} / \mathrm{m} 2$ ), overweight $(25 \mathrm{~kg} / \mathrm{m} 2 \mathrm{t} 030 \mathrm{~kg} / \mathrm{m} 2$ ) obese (more than $30 \mathrm{~kg} / \mathrm{m} 2$ ) 
Part two: Laboratory investigations :( pre-post tool):The pregnant women's hemoglobin level will be assessed 3 times during the study period, at first visit/first trimester, second and third trimester. Based on hemoglobin level Scoring system All patients with a value less than 11g/dL were considered anemic, Hemoglobin level less than $7 \mathrm{~g} / \mathrm{dl}$ indicates severe anemia, 7-9.9 g/dl moderate anemia, and level between 10.0-10.9 mild anemia (Mirzaie et al., 2010).

Part three: Medication prescribed: All drugs prescribed to the women for anemia management was registered for (dose, how to use this drug, side effect, and dose interval) were all recorded.

Pilot study :A pilot study was carried out on10 \%total sample of women the researcher was selected $10 \%$ from each center (about 18) who match with eligibility criteria in order to test the applicability of the tools, clarity and simplicity of the included questions as well as to estimate the average time needed to complete the sheets. Those who shared in the pilot study were excluded from the main study sample. Necessary modifications were carried out to develop the final form of the tools. The feasibility of the study and the applicability of the tool, were tested. find out the possible obstacles and problem that might face the researcher or interfere with data collection, detect any problems peculiar to the statement as sequences of question and clarity and estimate the time needed for data collection. The final form of the tool was formulated and the time needed for completing them was also determined, it was conducted over a period of one month from the beginning of June 2017.

Fieldwork: Data were collected over 12 months throughout the period from beginning of october2017 to october 2018 2months out of them for obtaining the official permission, pilot study, modification of tool next 6 months for data collection and implement the program next 2 months for follow up pregnant women and final months for data entry and statistically. An official approval was obtained from study setting to carry out the study. A clear explanation was given about the nature, and the expected outcomes of the study. All ethical issues were taken into consideration during all phases of the study; the researcher maintained an anonymity and confidentiality of the subjects. The researcher introduced herself to the women and briefly explained the nature and aim of the study to every woman before participation and obtained an oral consent from her. Women were assured that the information obtained during the study was confidential and used for the research purpose only. 
The researcher started to collect data and explain objectives of the study during the interview. The researcher started each phase with a summary for a previous one. The researcher used different teaching strategies (lectures, group discussion and booklet). For the study group the intervention program was applied to the same group and assessed preprogram immediately post and post 2 months of the program. For the control group, a questionnaire sheet was filled by the mothers under observation the researcher.

180 women randomly according to the distribution of previous table in sample setting by visiting Osman Ebn Afan Center Each Monday per week for 9 weeks each day attended 6 cases from 9 am t0 12 pm, visiting Elkwait center each Tuesday each week for 9 weeks and attended about 5-6 cases per day from 9 am t0 12pm, visiting Maternal and child first Arab each Monday in week for 4 week and attended about 5 cases per week from 9am t0 12 pm and visiting Elmanakh center each Tuesday in week for 4 week and attended 5-6 cases in day from 9am t0 $12 \mathrm{pm}$, visiting Port- Foad center for one week in Monday and Tuesday in this week from 9am t0 $12 \mathrm{pm}$ and finally visiting Elarab first for 2 weeks in Monday and Tuesday in this weeks and attended about 6 cases in day from 9 am t0 12 p.m. . The collected data served as a pre-test for baseline comparison with post-test data. It also helped the researcher to identify the educational needs of the participants in order to design the program.

Program development :The program was designed according to the information obtained from the pretest (questionnaire) the program was developed based on the results obtained from the interviewing questionnaire and literature review. The methods used in teaching the program was lectures, discussions \&illustrated booklet. Suitable teaching aids were prepared for the program application as booklet and boosters.

It was 12 group divided according to the number of pregnant women in maternal and child health care centers. each group about 6-8 pregnant women), At the beginning of the classes, a question and answer session was conducted for the initial survey of the women's knowledge, this was followed by a lecture, photographs, and training booklet, and then continued with group discussions. Physical assessment; pregnant women's weight, length and vital signs were measured at first visit, and at second and third trimester of pregnancy. The results of blood test /hemoglobin level was obtained from pregnant women record at first booking visit. The hemoglobin level was repeated at second and third trimester at Mother Child Health laboratory. 
Signs and symptoms denoting anemia were recorded. All participants were followed up by the researcher for a period of 2 months ( 8 weeks about 2 day per week). The program was administered to members of the study group only.

\section{Statistical design:}

The Statistical Package for Social Science (SPSS20) was used. Data was presented and a suitable analysis performed. Unpaired Student T-test was used to compare two independent groups regarding quantitative data.The Chi-square was used to compare qualitative variables. Pearson's correlation coefficient(r) test was used to assess the degree of association between two sets of variables. P-value $<0.05$ was considered significant.

\section{RESULT}

Table (1): shows that about (67.8\%) of patients in the study group was in the age group between 20-30 with a mean age of (25.84 \pm 4.39$)$, compared to those in the control group $(60.0 \%$, with a mean age $29.24 \pm 4.32$ respectively). Meanwhile, about (32.3\% vs $25.6 \%$ respectively) of the study and control groups had secondary level of education and about (65.6\% vs. 0.0\% respectively) were housewives. Moreover, about (37.8\%, 20.0\% respectively) had an income that meet their life expenses and about $(33.3 \%, 40.0 \%$ respectively) were living in rural areas

Table(2): indicates that the pregnant of women in both the study and control groups had their gestational age 12 weeks about ( $47.8 \%$ vs. $37.8 \%$ respectively) and about (33.3\% vs30\%) were in 14 weeks of gestational age. The table also shows that $16.7 \%$ of women in the study group were exposed to threatened abortion compared to $10.0 \%$ in the control group. Moreover, the women in the study group were overweight and obese (22.0\%) compared to $20.2 \%$ in the control group

Table (3): indicates that the irregularity in the intake of drug did significantly decrease at the second and third visit among the study group compared to those in the control group (5.9\% \& $0.0 \%$ vs. $75.0 \% \& 68.5 \%$ respectively). The reason behind this was mainly their failure to remember the drug and this was evident in the second visit and corrected at the third visit $80.0 \%$ \& $0.0 \%$ vs. $66.7 \%$ \& $37.5 \%$ respectively) It was observed that the statistically significant difference $(\mathrm{P}=0.001 *)$ 
Table (4): shows the distribution of the study subjects according to their mean hemoglobin level before and after the intervention. It is obvious that the mean hemoglobin level did statistically increase $\left(\mathrm{p}=0.001^{*}\right)$ among the study group after the second and third visit compared to those in the control group $(9.27 \pm 1.27 \& 11.8 \pm 0.7$ vs. $9.69 \pm 0.63 \& 9.89 \pm 1.02$ respectively).

Figure 1 displays the results of women total knowledge about iron deficiency anemia throughout program phases. It points to statistically significant improvements at post-test in the study group. The percent of women having satisfactory knowledge has increased from a pre-program level of $8.0 \%$ to a post-program level of $86.0 \%$, compared to those in the control group.

Table (5): shows that women dietary behaviors throughout program phases. It points to statistically significant improvements at the post-test $(\mathrm{p}<0.001)$. The intake of animal or plant proteins was very low in the study group $(6.0 \%)$ at the pre-program phase, and improved to $75.6 \%$ at post-tests. on the other hand, the majority of the study group ( $95.3 \%$ ) in study group pre intervention was eating chips and chocolate more than fruits and improved to 95.3\% post intervention and $96.0 \%$ of the study group drinking tea or cola with meal did obtain acceptable dietary habits compared to those in the control group $15.9 \%$ respectively

Table (6): demonstrates the positive mean level of women perception about Iron Deficiency Anemia in the study and control groups throughout intervention phases. Significant differences P $<0.05$ were observed in the study group for all HBM constructs, whereas no significant differences occurred in the control group $(\mathrm{p}=\mathrm{P}>0.05)$. 
Table 1: Socio - Demographic Characteristics for pregnant women according to their age, education level ,occupation ,monthly income, place of residence and family members $\quad(n=180)$

\begin{tabular}{|c|c|c|c|c|}
\hline \multirow{3}{*}{ Demographic data } & \multicolumn{4}{|c|}{ Groups } \\
\hline & \multicolumn{2}{|c|}{ Study $(\mathrm{n}=90)$} & \multicolumn{2}{|c|}{ Control $(n=90)$} \\
\hline & No & $\%$ & No & $\%$ \\
\hline \multicolumn{5}{|l|}{ Age (years) } \\
\hline$<20$ & 6 & 6.7 & - & - \\
\hline $20-30$ & 61 & 67.8 & 54 & 60.0 \\
\hline$\geq 30$ & 23 & 25.6 & 36 & 40.0 \\
\hline Mean \pm SD & \multicolumn{2}{|c|}{$25.84 \pm 4.39$} & \multicolumn{2}{|c|}{$29.24 \pm 4.32$} \\
\hline \multicolumn{5}{|l|}{ Educational level } \\
\hline Illiterate & 13 & 14.4 & 17 & 18.9 \\
\hline Read and write & 9 & 10.0 & 6 & 6.7 \\
\hline Basic school & 21 & 23.3 & 32 & 35.5 \\
\hline Secondary school & 29 & 32.3 & 23 & 25.6 \\
\hline University & 18 & 20.0 & 12 & 13.3 \\
\hline \multicolumn{5}{|l|}{ Occupation } \\
\hline House wife & 59 & 65.6 & - & - \\
\hline Government employee & 25 & 27.8 & 72 & 80.0 \\
\hline Nongovernmental employee & 6 & 6.7 & 18 & 20.0 \\
\hline \multicolumn{5}{|l|}{ Monthly income } \\
\hline Sufficient & 47 & 52.2 & 72 & 80.0 \\
\hline Just meet life expenses & 34 & 37.8 & 18 & 20.0 \\
\hline Insufficient & 9 & 10.0 & - & - \\
\hline \multicolumn{5}{|l|}{ Place of residence } \\
\hline Urban & 60 & 66.7 & 54 & 60.0 \\
\hline Rural & 30 & 33.3 & 36 & 40.0 \\
\hline \multicolumn{5}{|l|}{ Family members } \\
\hline Mean \pm SD & \multicolumn{2}{|c|}{$3.53 \pm 1.44$} & \multicolumn{2}{|c|}{$3.91 \pm 0.83$} \\
\hline
\end{tabular}


Table (2): Distribution of the Studied Women According to Current Pregnancy Data

(Gestational age, complain from threaten abortion and body mass index) $(n=180)$.

\begin{tabular}{|c|c|c|c|c|c|}
\hline \multirow{3}{*}{ History of present pregnancy } & \multicolumn{4}{|c|}{ Groups } & \multirow{3}{*}{$\mathrm{X}^{2}(\mathrm{P})$} \\
\hline & \multicolumn{2}{|c|}{ Study } & \multicolumn{2}{|c|}{ Control } & \\
\hline & No & $\%$ & No & $\%$ & \\
\hline \multicolumn{5}{|l|}{ Gestational age/weeks } & \multirow[b]{2}{*}{$4.6(0.325)$} \\
\hline $\begin{array}{l}12 \text { weeks } \\
14 \text { weeks } \\
15 \text { weeks } \\
16 \text { weeks }\end{array}$ & $\begin{array}{l}43 \\
30 \\
7 \\
10\end{array}$ & $\begin{array}{l}47.8 \\
33.3 \\
7.8 \\
11.1\end{array}$ & $\begin{array}{l}24 \\
27 \\
12 \\
17\end{array}$ & $\begin{array}{l}37.8 \\
30.0 \\
13.2 \\
18.9\end{array}$ & \\
\hline \multicolumn{5}{|l|}{$\begin{array}{l}\text { Complain of threatened abortion } \\
\text { during pregnancy }\end{array}$} & \multirow{2}{*}{$\begin{array}{l}5.5 \\
(0.019)^{*}\end{array}$} \\
\hline Yes & 15 & 16.7 & 9 & 10.0 & \\
\hline Body mass index(BMI) & & & & & MCP \\
\hline Normal & 42 & 46.7 & 42 & 46.7 & \multirow{3}{*}{0.079} \\
\hline Overweight & 28 & 31.1 & 27 & 33.3 & \\
\hline Obese & 20 & 22.2 & 21 & 20.0 & \\
\hline
\end{tabular}

$* \mathrm{P}<0.05$ (significant) 
Table3: The pattern of prescribed drug used among women in the study and control groups throughout intervention phases $(n=180)$

\begin{tabular}{|c|c|c|c|c|c|}
\hline \multirow{3}{*}{ Variables } & \multicolumn{4}{|l|}{ Group } & \multirow{3}{*}{$\mathrm{P}$} \\
\hline & \multicolumn{2}{|c|}{ Study $(n=90)$} & \multicolumn{2}{|c|}{ Control $(n=90)$} & \\
\hline & $2^{\text {nd }}$ visit & $3^{\text {rd }}$ visit & $2^{\text {nd }}$ visit & $3^{\text {rd }}$ visit & \\
\hline $\begin{array}{l}\text { Taking of prescribed } \\
\text { medication } \\
\text { ( iron Therapy) }\end{array}$ & & & & & $0.001 *$ \\
\hline Yes & $94 . .4$ & 100.0 & 22.2 & 38.9 & \\
\hline Method of iron intake & & & & & \\
\hline Oral & 100.0 & 97.8 & 100.0 & 80.0 & $0.004 *$ \\
\hline Injection & 0.0 & 2.2 & 0.0 & 20.0 & \\
\hline Pattern of iron use & & & & & \\
\hline Regular & 94.1 & 100.0 & 25.0 & 31.4 & \\
\hline Irregular & 5.9 & 0.0 & 75.0 & 68.5 & 0.001 \\
\hline Drinks taken with iron tablet & & & & & \\
\hline Water & 88.2 & 83.3 & 100.0 & 97.1 & \\
\hline Milk & 0.0 & 0.0 & 0.0 & 2.8 & $0.002 *$ \\
\hline Juice & 11.8 & 16.7 & 0.0 & 0.0 & \\
\hline $\begin{array}{l}\text { Causes of irregular intake of } \\
\text { iron therapy }\end{array}$ & $(n=5)$ & $(\mathrm{n}=0)$ & $(n=15)$ & $(n=24)$ & $0.001 *$ \\
\hline Forgetting & 80.0 & 0.0 & 66.7 & 37.5 & \\
\hline
\end{tabular}

$* \mathrm{P}<0.05$ (significant) 
Table (4): Comparison between the studied groups according to Hemoglobin level

\begin{tabular}{|l|l|l|l|l|l|l|}
\hline \multirow{2}{*}{ Hemoglobin level } & \multicolumn{3}{|l|}{ Study group $(\mathrm{n}=90)$} & \multicolumn{3}{l|}{ Control group $(\mathrm{n}=90)$} \\
\cline { 2 - 7 } & Pre & $\begin{array}{l}2^{\text {nd }} \\
\text { Trimester }\end{array}$ & $\begin{array}{l}3^{\text {rd }} \\
\text { Trimester }\end{array}$ & Pre & $\begin{array}{l}2^{\text {nd }} \\
\text { Trimester }\end{array}$ & $\begin{array}{l}3^{\text {rd }} \\
\text { Trimester }\end{array}$ \\
\cline { 2 - 7 } Mean \pm SD. & $\begin{array}{l}9.27 \pm \\
1.27\end{array}$ & $\begin{array}{l}10.18 \pm 0 . \\
76\end{array}$ & $11.8 \pm 0.7$ & $\begin{array}{l}9.69 \pm \\
0.63\end{array}$ & $9.77 \pm 1.12$ & $9.89 \pm 1.02$ \\
\hline F(p) & $\left.<0.001^{*}\right)$ & & 0.085 & & \\
\hline
\end{tabular}

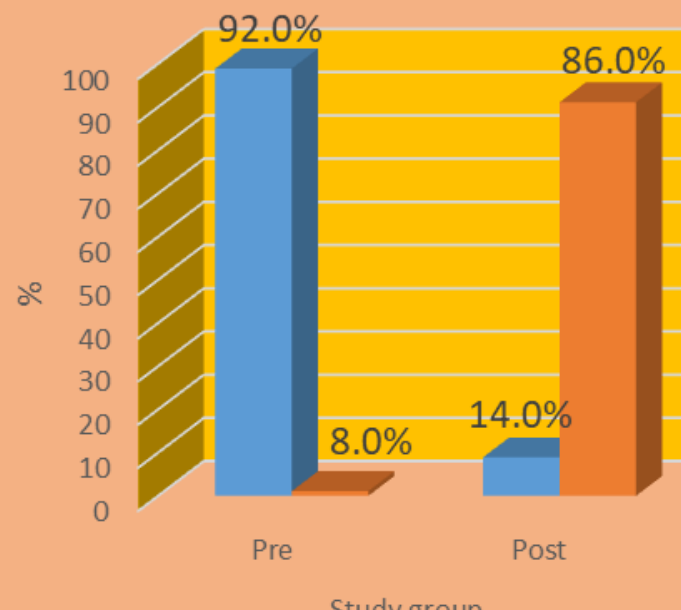

Study group

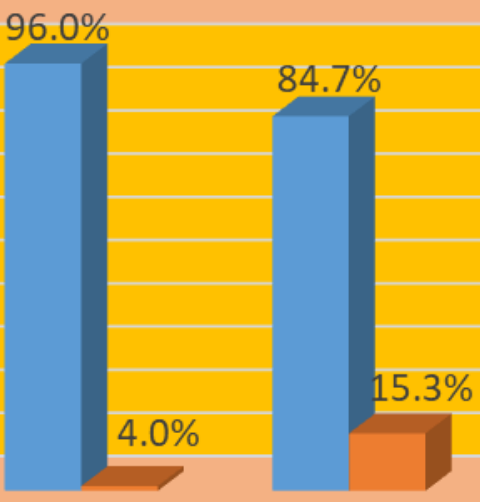

Pre

Unsatisfactory $\quad$ Satisfactory

Figure 1: Total Knowledge Score Pre and Post the Program 
Table (5): Dietary Habits among Women in the Study and Control Groups throughout intervention phases $(n=180)$

\begin{tabular}{|c|c|c|c|c|c|c|}
\hline \multirow[t]{2}{*}{ Variables } & \multicolumn{2}{|c|}{ Study group \% } & \multicolumn{2}{|c|}{ Control group\% } & \multirow{2}{*}{$\begin{array}{l}\text { MCP } \\
1 \\
\end{array}$} & \multirow{2}{*}{$\begin{array}{l}\text { MCP } \\
2\end{array}$} \\
\hline & Pre & Post & Pre & Post & & \\
\hline $\begin{array}{l}\text { Eating balanced diet (which is rich } \\
\text { in iron) } \\
\text { Satisfactory (Always) } \\
\text { Unsatisfactory(Never \& S0metime) }\end{array}$ & \begin{tabular}{|l|}
7.0 \\
93.0
\end{tabular} & $\begin{array}{l}75.0 \\
25.0\end{array}$ & $\begin{array}{l}8.9 \\
91.1\end{array}$ & $\begin{array}{l}9.9 \\
80.1\end{array}$ & 0.041 & $0.001 *$ \\
\hline $\begin{array}{l}\text { Eating plant and animal proteins } \\
\text { Satisfactory (Always) } \\
\text { Unsatisfactory (Never \& } \\
\text { Sometime) }\end{array}$ & \begin{tabular}{|l|}
6.0 \\
94.0
\end{tabular} & $\begin{array}{l}75.6 \\
24.4\end{array}$ & \begin{tabular}{|l}
6.1 \\
95.9
\end{tabular} & $\begin{array}{l}8.1 \\
92.9\end{array}$ & 0.014 & $0.002 *$ \\
\hline $\begin{array}{l}\text { Eating row green vegetables\& } \\
\text { fruits daily } \\
\text { Satisfactory (Always) } \\
\text { Unsatisfactory (Never \& } \\
\text { Sometime) }\end{array}$ & \begin{tabular}{|l}
20.5 \\
79.5
\end{tabular} & $\begin{array}{l}94.0 \\
6.0\end{array}$ & $\begin{array}{l}20.8 \\
79.2\end{array}$ & $\begin{array}{l}23.8 \\
76.2\end{array}$ & 0.075 & $0.001 *$ \\
\hline $\begin{array}{l}\text { Drinking tea or cola with meal } \\
\text { Satisfactory (Never) } \\
\text { Unsatisfactory (Always \& } \\
\text { Sometime }\end{array}$ & \begin{tabular}{|l}
15.8 \\
84.2
\end{tabular} & $\begin{array}{l}96.0 \\
4.0\end{array}$ & $\begin{array}{l}14.4 \\
85.6\end{array}$ & $\begin{array}{l}15.9 \\
84.1\end{array}$ & 0.084 & $0.001 *$ \\
\hline $\begin{array}{l}\text { Preferring specific type of } \\
\text { regardless of its nutritional value } \\
\text { (Salty fish, Herring, Pickles) } \\
\text { Satisfactory (Never) } \\
\text { Unsatisfactory (Always \& } \\
\text { Sometime) }\end{array}$ & \begin{tabular}{|l|}
30.7 \\
69.3
\end{tabular} & $\begin{array}{l}82.1 \\
17.9\end{array}$ & \begin{tabular}{|l|}
5.6 \\
94.4
\end{tabular} & $\begin{array}{l}7.5 \\
92.5\end{array}$ & 0.844 & $0.001 *$ \\
\hline $\begin{array}{l}\text { Eating chips and chocolate more } \\
\text { than fruits } \\
\text { Satisfactory (Never) } \\
\text { Unsatisfactory (Always \& } \\
\text { Sometime) }\end{array}$ & \begin{tabular}{|l}
10.4 \\
89.6
\end{tabular} & $\begin{array}{l}95.3 \\
4.7\end{array}$ & $\begin{array}{l}12.8 \\
87.2\end{array}$ & $\begin{array}{l}12.3 \\
77.7\end{array}$ & 0.064 & $0.004 *$ \\
\hline
\end{tabular}

MCP: Mont Carlo exact probability MCP 1 Pre vs. Pre MCP 2 Post vs. Post

$* \mathrm{P}<0.05$ (significant) 
Table (6): Comparison between the studied groups according to food Health Believe Model constructs throughout Intervention phases (Pregnant women's perception Pre training to IDA) $(\mathrm{N}=180)$

\begin{tabular}{|c|c|c|c|c|}
\hline & \multicolumn{2}{|l|}{ Study } & \multicolumn{2}{|l|}{ Control } \\
\hline & \multicolumn{2}{|l|}{ Mean \pm SD } & \multicolumn{2}{|c|}{ Mean \pm SD } \\
\hline & Pre & P0st & Pre & P0st \\
\hline $\begin{array}{l}\text { Perceived risk of iron } \\
\text { deficiency anemia }\end{array}$ & $\begin{array}{l}13.52 \pm \\
2.34\end{array}$ & $\begin{array}{l}16.64 \pm \\
1.49\end{array}$ & $11.9 \pm 2.1$ & $11.8 \pm 1.8$ \\
\hline $\mathrm{P}+$ & \multicolumn{2}{|l|}{$0.001 *$} & \multicolumn{2}{|l|}{0.437} \\
\hline $\begin{array}{l}\text { Perceived susceptibility to iron } \\
\text { deficiency anemia }\end{array}$ & $6.42 \pm 1.24$ & $7.42 \pm 1.36$ & $6.6 \pm 0.8$ & $6.7 \pm 0.8$ \\
\hline $\mathrm{P}+$ & \multicolumn{2}{|l|}{$0.001 *$} & \multicolumn{2}{|l|}{0.850} \\
\hline Perceived Benefits & $3.0 \pm 0.0$ & $10.4 \pm 0.4$ & $2.8 \pm 0.5$ & $3.1 \pm 0.6$ \\
\hline $\mathrm{P}+$ & \multicolumn{2}{|l|}{$0.001^{*}$} & \multicolumn{2}{|l|}{0.551} \\
\hline Perceived Barriers & $8.88 \pm 2.0$ & $11.7 \pm 1.5$ & $7.6 \pm 1.1$ & $7.9 \pm 1.2$ \\
\hline $\mathrm{P}+$ & \multicolumn{2}{|l|}{$0.003^{*}$} & \multicolumn{2}{|l|}{0.907} \\
\hline Self-Efficacy & $5.0 \pm 0.0$ & $6.2 \pm 1.0$ & $3.7 \pm 0.8$ & $4.1 \pm 0.9$ \\
\hline $\mathrm{P}+$ & \multicolumn{2}{|l|}{$0.004 *$} & \multicolumn{2}{|l|}{0.907} \\
\hline Cues to Action & $5.3 \pm 1.2$ & $8.6 \pm 1.3$ & $5.2 \pm 1.3$ & $5.4 \pm 1.4$ \\
\hline $\mathrm{P}+$ & \multicolumn{2}{|l|}{$0.001^{*}$} & \multicolumn{2}{|l|}{0.986} \\
\hline
\end{tabular}

$\mathrm{P}+: \mathrm{P}$ value of Paired t-test

$* \mathrm{P}<0.05$ (significant) 


\section{DISCUSSION:}

Anemia is a condition in which the number of red blood cells (and consequently their oxygen-carrying capacity) is insufficient to meet the body's physiologic needs. Specific physiologic needs vary with a person's age, gender, residential elevation above sea level (altitude), smoking behavior, and different stages of pregnancy. Iron deficiency is thought to be the most common cause of anemia globally, during pregnancy (Getahun,et al., 2017).

It was thrilling to find out in the present finding that a large percentage of the studied women were overweight and obese. This study is disagree with study In contrary, (Moradi, et al., 2018) that found that IDA was more common among women who possess normal body weight in my opinion it may be due to unhealthy food as fast food that lead to obesity with no exercises The discrepancies between the present study finding and the previous one might be related to the culture of the society and non- healthy nutritional practices.

The present study finding revealed that a hemoglobin level was elevated among the study group during the first and second assessment compared to those in the control group. This finding is in line with (Thompson, \& Darwish,2019) about Environmental chemical contaminants in food: review of a global problem. Reported a rise in HB level among the study group during the period between 4-9 months of pregnancy after the application of the intervention program. Meanwhile, ( Mageed et al., 2017) found that by the application of Complementary Nutritional Intervention program (CNI), the mean $\mathrm{HB}$ pre-program was

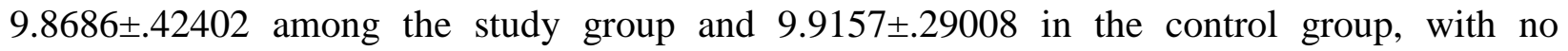
significant difference between the study and control groups. It may be due to effective management protocol and good health education by using health believe model.

These results imply an increase in the mothers' perception of the benefits of healthy dietary pattern modifications over time, and the women are likely to be more sensitive to the health of their fetus and infant among Intervention group. The importance of correct nutrition notwithstanding, it may also contribute to the prevention of obstetric complications, such as; severe bleeding leading to anemia, impaired wound healing and delayed recovery after childbirth. As emphasizing HBM constructs to change women behavior and attitude and its 
process, which followed the principles of women, learning with more active participation and open discussions. While no improvement was witnessed in the control group.

In this respect this study agree with (Mageed et al., 2017) that found a high significant difference $(\mathrm{p}<0.001)$ in relation to the mean scores of knowledge among the studied pregnant women regarding IDA pre versus after intervention of nutritional educational guideline (NEG). They explained this by the fact that the implementation of the NEG helped pregnant women to identify different sources of iron rich foods, regulate their time to take iron supplementation, and overcome side effects of iron supplementation.

In the opposite manner this study disagree with ( Khoramabadi et al., 2016) study in Iran about Effects of Education Based on Health Belief Model on Dietary Behaviors of Iranian Pregnant Women, observed, no significant differences between the two groups in terms of dietary behaviors, pre- intervention. In addition, after the intervention, in my opinion, decrease awareness of pregnant women about healthy dietary practice.

The current study aimed also to develop improve pregnant women's dietary practices. The study findings revealed major deficiencies in their daily intake of balanced diet before the intervention. The discoveries revealed low levels of dietary knowledge and misconceptions among women. As preferred takeaway and junk foods by many women as well as unhealthy dietary habits in cooking, saving foods as may destroy iron and other micronutrients. The application of our study guided a significant improvement among women in the study group in their daily intake of food groups, eating habits, and cooking practices compared to those in the control group. The foregoing findings confirm the positive effect of the educational program in improving the dietary habits of pregnant women by simple applications of information. on the same line this study agree with (Murrin et al. 2007) which concluded that a large proportion of reproductive-aged women internationally fail to meet food group recommendations., also a cross-sectional study conducted in primiparous mothers in southwestern Sydney revealed that low proportions of mothers were meeting the recommended intake of vegetables or fruit as well as essential diet containing iron during pregnancy (Wen et al., 2010) it may be due to unhealthy cooking and dietary habits or low income and educations. 
The similar finding was reported by (AL-Tell et al., 2010) who found that a positive relationship between pregnant women's perception level regarding anemia and their eating practices and significant difference was noticed when comparing study with control group reported the similar finding. In the same manner, this study is agree with Khoramabadi et al., (2016) study in Iran about Effects of Education Based on Health Belief Model on Dietary Behaviors of Iranian Pregnant Women, observed, no significant differences between the two groups in terms of dietary behaviors, pre- intervention. But after the intervention, $86.7 \%$ of women in experimental and 13.3\% of women in the control groups, were in level 3 of dietary behaviors (optimal dietary behaviors), which indicates that the majority of women who received educations based on the HBM, achieved optimal dietary behaviors.

The finding of the present study was expected in relation to HBM model constructs, thus, there were statistical differences for all variables post intervention among the study group compared with the control group. Similar finding was reported, that the study is agree with, by( Oriji, et al (2011) study about factors determining compliance to routine iron supplementation in pregnancy at the University of Portharcout Teaching Hospital, who found that perceived susceptibility, seriousness of anemia is associated with health behaviors in preventing and treatment of IDA in pregnant women.

\section{CONCLUSION:}

According to the result of this study health believe model enabling pregnant women to increase control over, and to improve their health. It movies, beyond focus on individual behavior towards a wide range of social and environmental interventions which in turn improve their anemia and their life style regarding their diet knowledge and practice

\section{RECOMMENDATION:}

1-Continuous health educations about Risk of anemia and its complications for pregnant women and her baby use assistant teaching as boosters, booklets, Healthy cooking and dietary health habits in antenatal care centers. 
2- Developing instruction plan based on signs and symptoms of IDA and its complications for the pregnant women and her baby.

3- Improve knowledge and practice about IDA in pregnant women

4- Physical activity should be encouraging for healthy lifestyle as exercise, how to fight obesity using assistant

5-Adopt healthy behaviors, to raise their awareness about hazards of anemia risk and reinforce competence in teaching as boosters

6- Further study for including issue about anemia and it's prevention ways within premarital counselling.

\section{REFERENCES:}

Abdelhafez, A., El-Soadaa, S.(2012): Prevalence and Risk Factors of Anemia among a Sample of Pregnant Females Attending Primary Health Care Centers in Makkah, Saudi Arabia. Pakistan Journal of Nutrition; 11 (12): 1113-1120. ISSN 1680-5194

Addis Alene, K., Mohamed Dohe, A. (2014). Prevalence of anemia and associated factors among pregnant women in an urban area of Eastern Ethiopia. Anemia, 2014.

Ainsworth,M.,Coskun,M.,Weiss,G.,(2015) managment of iron deficiency anemia

AL-TELL, M., EL-GUINDI, F., SOLIMAN, N., \& EL-NANA, H. (2010). Effect of Nutritional Interventions on Anemic Pregnant Women's Health Using Health Promotion Model. The Medical Journal of Cairo University, 78(2).

Gautam, C., Saha, L., Sekhri, K., and Saha,P. (2008): iron Deficiency in Pregnancy and the Rationality of iron supplement Prescribe during Pregnancy. Medscape. J. Med; 10: 283.

(Khoramabadi, M., Dolatian, M., Hajian, S., Zamanian, M., Taheripanah, R., Sheikhan, Z., ... \& Seyedi-Moghadam, A. (2016). Effects of education based on health belief model on dietary behaviors of Iranian pregnant women. Global journal of health science, 8(2), 230.). 
Mageed, A., Moustafa, H., Nour Eldin, S., Abd Allah, I., \& Amasha, H. (2017). The Impact of Management Protocol on Pregnant Women with Iron Deficiency Anemia Using Health Promotion Model. Zagazig Nursing Journal, 13(2), 67-85

Mirzaie, F., Eftekhari, N., Goldozeian, S., Mahdavinia, J. (2010): Prevalence of anemia risk factor in pregnant. Women Kerman. IJRM; 8: 66-69.

Moradi, S., Arghavani, H., Issah, A., Mohammadi, H., \& Mirzaei, K. (2018). Food insecurity and anaemia risk: a systematic review and meta-analysis. Public health nutrition, 21(16), 3067-3079.

Oriji, V., Enyindah, C., \& Nyeche, S. (2011). Factors determining compliance to routine iron supplementation in pregnancy at the University of Portharcout Teaching Hospital. Nigerian journal of medicine: journal of the National Association of Resident Doctors of Nigeria, 20(1), 131-134.

Thompson, L., \& Darwish, W. (2019). Environmental chemical contaminants in food: review of a global problem. Journal of toxicology, 2019.

Wen,W.,Stevenson,A., Wang, C.,Chen, H.,Kearsey, S.,Norbury,C,,Watt,S.,Bahlre,J.(2010)

World Health Organization,s Bangkok charter for health promotion (2005) 
ارشادات تحسين الصحة للسيدات الحوامل المصابات بانيميا نقص الحديد في مدينة بورسعيد

\section{بسمة قاسم براوي 1، أ .د/ جهاد محمد أبو المعاطى2، أ .م. د / إنعام حسن عبدالعاطى 3، د. / ناهد عبد العظيم عبدالسلام 4 ماجستير تمريض صحة الاسرة و المجتمع 1 ، أستاذ تمريض صحة الاسرة و المجتمع2 ، استاذ مساعد تمريض

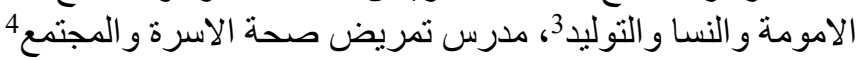

\section{الخلاصه}

تعزيز الصحة هو عملية تمكين الناس على صحتهم وتحسينها.من حيث التركيز على السلوك الفردي نحو مجموعة واسعة من التدخلات الاجتماعية والبيئية وتعرف انيميا الحديد اثناء الحمل بأنها قلة الهيموجلوبين عن110 غر ام / لتر. الهدف : تقييم تأثيرتطبيق ارشادات نعزيز الصحة للنساء الحوامل المصابات بنقص الحديد باستخدام نموذج تعزيز الصحة على تغيير تصور هم وسلوكهم. تصميم البحث: تم استخدام تصميم شبة تجريبى .المكان" أجريت الدراسة في ستة مر اكز للرعاية الصحية الاولية في مدينة بورسعيد. نوع العينة؛ عينة هادفة في هذه الدراسة وكان حجم العينة 180 امر أة حامل مقسمة إلى 90 سيدة مجمو عة در اسة و 90 سيدة مجموعة مر اقبة. أدوات جمع البيانات؛ وقد استخدمت ثلاث ادوات لجمع البيانات و هي استمارة الاستبيان التي تحتوي على أربعة أجز اءو استبيان تكرار الغذاء و السجلات التى تتضمن تقييم الفحوصات المختبرية. نتائج الاراسة و أنشارت النتائج إلى أن غالبية النساء الحوامل حصلن على مستوى ثانوي من التعليم وحوالي 65.6 في المائةمن ربات بيوت، وحو الي 94.7 منهن فترة قصيرة>2 سنة من الحمل السابق وحو الي 28.9 في المائة لا يستخدمن أي طريقة، مع عدم وجود اختلافات كبيرة بين المجموعتين حول علامات وأعر اض فقر الدم الناجم عن نقص الحديد ـ يرتبط الانيميا مع انخفاض مستوى التعليم و البيئة الاجتماعية. التي كانت غالبية النساء في كلتا المجموعتين على مستوى التعليم الثانوي وربات البيوت. أكثر من ثلاثة خمس النساء في كلتا الدراسة كانت حاملا مرتين أو ثلاث مر ات، مع عدم وجود اختلافات ذات دلالة إحصائية. غالبية النساء اللواتي تمت دراستهن لديه فترة قصيرة (>years2). الخلاصة : فقر الدم هو مشكلة صحية عالمية تؤثر على كل من الدول النامية والمتقدمة ويِرتبط مع انخفاض مستوى التعليم والبيئة الاجتماعية لذلك فان تطبيق ارشادات باسنخدام نموذج تعزيز الصحة كان له اثر ايجابى ذا دلالة احصائية على مجموعة الدر اسةفيما يخص معلوماتهن وممارستهن و زيادة مستوى الهيموجلوبين مقارنة بالمجموعة الضابطة التوصيات: تطوير المشورة قبل الزواج حول فقر الدم وكيفية 